\title{
AGENDA MEDIA TERHADAP ISU PERBATASAN KALIMANTAN BARAT PADA HARIAN PONTIANAK POST DAN TRIBUN PONTIANAK
}

\author{
Acan Mahdi
}

\begin{abstract}
Abstrak
Tulisan ini adalah upaya mengungkap sejauh mana suratkabar Pontianak Post dan Tribun Pontianak memberitakan mengenai isu perbatasan Kalimantan Barat. Dengan menggunakan teori agenda setting penelitian ini memperlihatkan perbedaan antara suratkabar Pontianak Post dan Tribun Pontianak dalam "melihat" isu perbatasan.
\end{abstract}

Kata Kunci: agenda media, isu perbatasan, suratkabar

\section{A. Pendahuluan}

Letak geografis Kalimantan Barat meninggalkan setumpuk cacatan suram kehidupan bernegara masyarakat perbatasan. Hidup berdampingan dengan negara tentangga, bukan menjadi berkah bagi masyarakat yang tinggal di perbatasan. Sebaliknya, menguak ketertinggalan dan keterbatasan masyarakat dalam kehipuan berbangsa dan bergegara. Karena posisi yang berdampingan, membuat ketimpangan semakin tajam dalam berbagai bidang kehidupan.

Masalah penyiaran di daerah perbatasan adalah wajah suram Kalimantan Barat di sisi yang lain. Masyarakat diperbatasan lebih nyaman menikmati penyiaran negara tetangga, dibandingkan negara sendiri. Akses terhadap penyiaran negara sendiri yang susah membuat masyarakat perbatasan terpaksa menyaksikan penyiaran negara tentangga. Akses masyarakat terhadap penyiaran dalam negeri sangat mahal. Hanya masyarakat mampu secara ekonomi, yang dapat menikmati siaran dalam negeri, dengan membeli atau memasang parabola. Pengalaman yang sama ketika dulu, waktu peneliti masih duduk di Sekolah Dasar sekitar tahun 1993. Kebetulan peneliti tinggal di pedalaman pada saat itu, tepatnya di kecamatan Nanga Taman Kabupaten Sekadau. Waktu itu, kita hanya bisa 
menyaksikan TV 3 Malaysia, karena pada saat itu belum populer parabola.

Terkait penyiaran di perbatasan ini, laporan Komisi Penyiaran Indonesia (KPI) 2013 mensinyalir ada beberapa kendala teknis penyiaran di perbatasan Kalimantan Barat sebagai berikut:

Tabel 1.1. Masalah Penyiaran di Perbatasan

\begin{tabular}{|c|c|c|}
\hline Bentuk Lembaga & Lokasi & Problem \\
\hline $\begin{array}{l}\text { Radio Kimtas: } \\
\text { Bantuan dari } \\
\text { Depkominfo dan } \\
\text { BPPT (Proyek) }\end{array}$ & \begin{tabular}{|l} 
Sanggau, \\
Sambas, \\
Bengkayang
\end{tabular} & $\begin{array}{l}\text { Status tidak jelas, hal ini } \\
\text { berkonsekuensi pada } \\
\text { keberlanjutan pengelolaan (dana). } \\
\text { Lemahnya SDM pengelola. } \\
\text { Badan hukum tidak jelas } \\
\text { Daya jangkau terbatas. }\end{array}$ \\
\hline $\begin{array}{l}\text { Televisi } \\
\text { Perbatasan } \\
\text { Bantuan dari } \\
\text { Depkominfo dan } \\
\text { BPPT (Proyek) }\end{array}$ & $\begin{array}{l}\text { Sambas dan } \\
\text { Sanggau, }\end{array}$ & $\begin{array}{l}\text { Sumber energi listrik tidak memadai. } \\
\text { SDM pengelola lemah. } \\
\text { Status badan hukum tidak jelas. }\end{array}$ \\
\hline $\begin{array}{l}\text { Radio Komunitas } \\
\text { (Swadaya) }\end{array}$ & $\begin{array}{l}\text { Seluruh } \\
\text { kabupaten }\end{array}$ & $\begin{array}{l}\text { Daya jangkau terbatas. } \\
\text { Dukungan finansial lemah. } \\
\text { Belum mendapat perhatian Pemda } \\
\text { lokal. } \\
\text { Perizinan rumit. }\end{array}$ \\
\hline $\begin{array}{l}\text { LPP (Radio) Lokal } \\
\text { (EKSP RSPD) }\end{array}$ & $\begin{array}{l}\text { Sanggau, Kapuas } \\
\text { Hulu }\end{array}$ & $\begin{array}{l}\text { Badan hukum belum jelas } \\
\text { Dukungan Pemda lemah }\end{array}$ \\
\hline LPP RRI & \begin{tabular}{|l|} 
Sanggau \\
(Entikong), \\
Sambas, Sintang, \\
dan Pontianak
\end{tabular} & $\begin{array}{l}\text { Hanya } 2 \text { stasiun } 1 \text { stasiun } \\
\text { persiapan (entikong) } \\
\text { Daya jangkau belum memadai }\end{array}$ \\
\hline LPP TVRI & Satelit & $\begin{array}{l}\text { Masih ada masalah teknis } \\
\text { Keterjangkauan biaya parabola } \\
\text { Jam siaran lokal masih terbatas }\end{array}$ \\
\hline
\end{tabular}

Gelapnya dunia perbatasan juga dapat dilihat dari aksesabilitas pendidikan bagi masyarakat perbatasan. Eusabinus dkk, (tanpa tahun) memperlihatkan data kuantitaif akses pendidikan yang rendah.. Menurut hasil penelitian ini 456 atau 18,38\% dari 2479 lulus sekolah dasar atau sederajat tahun 2008/2009 di kecamatan Paloh, Subah, Sajingan, dan Teluk Keramat, kabupaten Sambas tidak melanjutkan pendidikannya ke jenjang yang lebih tinggi. Sementara dikecamatan Entikong,
Sekayam, Beduai dan Kembayan kabupaten Sanggau, hanya 305 atau $17,93 \%$ lulusan sekolah dasar sederajat tahun 2008/2009 tidak melanjutkan pendidikannya ke jenjang yang lebih tinggi. Faktor penghambat untuk meneruskan pendidikan menurut laporan ini meliputi: sosial budaya, ekonomi, geografi dan demokrafi.

Traficking, adalah momok yang selalu menghantui masyarakat Kalimantan Barat. Menempati wilayah perbatasan secara geografis, menjadikan Kalimantan Barat sangat "dekat" dengan traficking. Pemerintah Daerah Kalimantan Barat sebenarnya sudah berupaya mengatasi traficking ini dengan menerbitkan Peraturan Daerah Provinsi Kalimantan Barat Nomor 7 Tahun 2007 Tentang Pencegahan dan Pemberantasan Tindak Pidana Perdagangan Orang terutama perempuan dan anak. Namun upaya ini masih kurang maksimal. Menurut Sri Rahayu (tanpa tahun) upaya pemerintah ini tidak efektiv dan kurang maksimal, karena di antaranya adalah kemiskinan yang tinggi dan lapangan pekerjaan yang minim.

Upaya untuk mengatasi berbagai persoalan diperbatasan terus dilakukan. Penelitian yang dilakukan Mufizar (2012) memperlihatkan upaya pemerintah Kabupaten Sambas mengatasi maslah 
pendidikan di daerah perbatasan khususnya Kecamatan Sajingan Besar, dengan membangun Sekolah Menengah Atas (SMA) terpadu yang merupakan sekolah unggulan di mana diharapkan mutu pendidikan di daerah perbatasan dapat mengimbangi kemajuan-kemajuan khususnya pendidikan di perbatasan Malaysia. Selain bidang pendidikan, penelitian ini juga menunjukkan usaha pemerintah untuk menjamin akses kesehatan masyarakat perbatasan dengan membangun sarana kesehatan agar kesehatan masyarakat lebih baik, dengan dibangunnya polindes-polindes di desa-desa terpencil dimaksudkan agar jarak tempuh masyarakat dengan pelayanan kesehatan lebih dekat.

Partnership Policy Paper No. 2/2011 melansir enam permasalahan yang ada di kawasan perbatasan pada umumnya meliputi:

Pertama, Belum adanya kepastian dan ketegasan garis batas, baik garis batas laut maupun garis batas darat, serta administrasi dan pemeliharaannya. Akibatnya perencanaan pembangunan wilayah perbatasan menjadi terkendala. Adanya permasalahan batas negara ini banyak menimbulkan dampak negatif dan berbagai insiden di perbatasan dan pelanggaran wilayah kedaulatan.
Kedua, Kondisi masyarakat di kawasan perbatasan pada umumnya masih miskin, tertinggal, terbelakang, tingkat pendidikan dan kesehatan rendah, serta secara komunitas terisolir.

Ketiga, Lemahnya penegakan hukum, menyebabkan maraknya pelanggaran hukum di kawasan perbatasan. Implementasi pos-pos perbatasan dan fasilitasi bea cukai, imigrasi, dan karantina (CIQ/Custom, Imigration and Quarantina) tidak optimal dan terkendala banyak hal, sehingga mengakibatkan terjadinya berbagai kegiatan ilegal lintas batas.

Empat, Belum sinkronnya pengelolaan kawasan perbatasan, baik menyangkut kelembagaan, program, maupun kejelasan wewenang.

Lima, Adanya kegiatan penyelundupan barang dan Tenaga Kerja Indonesia (TKI)

Enam, Rentannya persoalan yang terkait dengan nasionalisme penduduk karena kurangnya informasi yang masuk dari Indonesia, dan masyarakat di kawasan perbatasan lebih mengenal negara tentangga daripada negara sendiri.

Secara khusus, Partnership Policy Paper No. 2/2011 juga melansir permasalahan pengelolaan yang terjadi diperbatasan Kalimantan Barat. Pertama, Belum jelasnya penataan ruang dan 
pemanfaatan sumber daya alam. Kondisi ini ditunjukkan dengan terjadinya konflik ataupun tumpang tindih pemanfaatan ruang (lahan) baik antara kawasan budidaya dengan kawasan lindung, maupun antar kawasan budidaya seperti kegiatan pertambangan dan kehutanan yang berkaitan dengan ekonomi daerah dan masyarakat.

Kedua, Kawasan perbatasan sebagai daerah tertinggal Kawasan perbatasan di kabupaten Sanggau dan Sambas, masuk dalam kategori daerah tertinggal karena kurangnya perhatian pemerintah. Kebijakan pembangunan saat ini cenderung menjadikan dua kawasan perbatasan hanya difungsikan sebagai sabuk keamanan.

Ketiga, kendala geografis. Secara geografis kawasan perbatasan merupakan daerah yang sangat luas. Di Kalimantan Barat saja panjang garis perbatasan $966 \mathrm{~km}$, sehingga cukup menyulitkan dalam penanganan terutama ditinjau dari aspek rentang kendali pelayanan, kebutuhan dana, dan kebutuhan aparatur. Kondisi ini semakin diperparah oleh kondisi infrastruktur jalan yang relatif sangat terbatas baik kualitas maupun kuantitasnya.

Empat, Adanya inkonsistensi antara perencanaan dengan pelaksanaan. Di dalam Garis Besar Haluan Negara (GBHN) 1999 - 2004 dan dalam Program Pembangunan Nasional (Propenas) 2000 - 2004 telah diamanatkan perlunya arah kebijakan dan program pembangunan wilayah perbatasan, namun pada tataran implementasi tidak terbukti, karena selama periode 1999 - 2004 tidak terjadi peningkatan kegiatan pembangunan yang signifikan di kawasan perbatasan. Untuk pasca 2004, pembangunan kawasan perbatasan belum menjadi prioritas kebijakan nasional.

Lima, Ketidakjelasan wewenang dan koordinasi Penanganan masalah di kawasan perbatasan membutuhkan landasan hukum yang tegas, komprehensif dan mampu mengikat semua pihak. Salah satunya adalah kejelasan wewenang dan jalur koordinasi dalam pengelolaan kawasan perbatasan. Tidak jarang masing-masing level pemerintahan berebut pengaruh di perbatasan ketika ada potensi penerimaan dan lepas tanggung jawab pada saat timbul masalah.

Enam, Rendahnya sumber daya manusia (SDM). Kondisi ini ditunjukkan dengan rendahnya tingkat pendidikan dan kualitas kesejahteraan penduduk dengan penyebaran yang tidak merata dibandingkan dengan luas wilayah dan garis perbatasan yang panjang, sehingga berimplikasi pada kegiatan pelintas batas yang ilegal. Demikian pula banyak TKI 
maupun TKW yang bekerja di luar negeri hanya sebagai buruh, pembantu rumah tangga dan pekerja kasar lainnya, yang jelas-jelas menggambarkan rendahnya kualitas SDM pada umumnya.

Tujuh, kemiskinan. Walaupun saat ini kawasan perbatasan kaya dengan sumber daya alam dan letaknya mempunyai akses ke pasar (Serawak), tetapi terdapat sekitar $45 \%$ desa miskin dengan jumlah penduduk miskin sekitar 35\%. Jika dibandingkan dengan penduduk Malaysia tampak adanya ketimpangan pendapatan yang besar sekali. Akibatnya penduduk di kawasan perbatasan tidak memiliki posisi tawar yang sebanding dalam kegiatan ekonomi di perbatasan. Akibat lainnya adalah mendorong masyarakat semakin terlibat dalam kegiatan ekonomi ilegal guna memenuhi kebutuhannya.

Namun demikian, kita boleh menyerah dengan fakta yang ada. meski ada upaya untuk mengatasinya. Melalui penelitian, Rahayu menoreskan catatan mengenai upaya pemerintan misalnya dalam mengatasi maslah traficking meski belum maksimal. Namun setidaknya kita sudah berbuat.

Upaya-upaya semacam ini tentu menjadi tanggung jawab bersama. Apalagi jika kita hanya melemparkan tanggung jawab tersebut hanya kepada pemerintah. Harus ada kerjasama yang baik antara pemerintah dangan semua elemen masyarakat.

Media massa merupakan pihak yang juga harus memikul tanggung jawab ini. Ekspose media massa terhadap persoalan perbatasan menjadi sangat penting dalam membantu upaya perbaikan kehidupan masyarakat perbatasan. Mengingat kemampuan media dalam membentuk opini dan sikap masyarakat. Hal ini sesuai edealisme jurnalistik sebagai kontrol sosial dan menjaga nilai-nilai yang berlaku dalam masyarakat.

Persoalannya adalah, sejauh mana media massa di Kalimantan Barat menempatkan isu perbatasan ini menjadi sebuah perhatian yang serius? Mengingat media massa juga memiliki edialisme sendiri, apalagi jika dikaitkan dengan mekanisme pasar yang menjadikan kapital sebagai alat ukur. Untuk menjawab pertanyaan inilah penelitian ini ada. Penelitian ini adalah upaya melihat bagaimana media massa Kalimantan Barat menempatkan isu-isu perbatasan dalam pemberitaannya, terutapa pada suratkabar Harian Pontianak Post dan Tribun Pontianak.

\section{B. Masalah}

Berdasarkan latar belakang di
atas, penelitian ini merumuskan
pertanyaan penelitian sebagai berikut


"bagaimanakah isu perbatasan

Kalimantan Barat diberitakan pada suratkabar Harian Pontianak Post, Tribun Pontianak?'

Fokus penelitian di atas masih sangat umum, karena itu penelitian ini mencoba menggali lebih dalam mengenai bagaimana Harian Pontianak Post dan Tribun Pontianak memberitakan isu perbatasan di Kalimantan Barat. Rumusan masalah tersebut akan dijabarkan dalam pertanyaan penelitian sebagai berikut:

1. Bagaimanakah intensitas antara Harian Pontianak Post dan Tribune Pontianak dalam memberitakan isu perbatasan Kalimantan Barat?

2. Apakah ada persamaan dan perbedaan antara harian Pontianak Post dan Tribun Pontianak dalam menentukan berita headline terkait isu perbatasan?

\section{Pembahasan}

\section{Intensitas antara Harian Pontianak Post dan Tribun Pontianak dalam memberitakan isu perbatasan Kalimantan Barat}

Dalam agenda suratkabar Harian Pontianak Post dan Tribun Pontianak terdapat perbadaan kedua media tersebut dalam "pembacaannya" terhadap isu perbatasan. Berdasarkan data penelitian sebagaimana yang telah dipaparkan di atas, Harian Pontianak Post lebih intensif dalam mewacanakan pemberitaan mengenai isu perbatasan dibandingkan suratkabar Harian Tribun Pontianak.

Selama pengamatan peneliti dilapangan, dalam bulan Agustus tahun 2015 Harian Pontianak Post menurunkan sembilan artikel mengenai perbatasan. Dalam agendanya terhadap isu perbatasan, berbagai macam persoalan "diangkat" Harian Pontianak Post dilihat dari topik pembicaraannya. Artikel 1 misalnya mengangkat mengenai gula ilegal dari Malaysia. Kemudian, artikel 2 membicarakan menganai gelar eksaminasi legal pengelolaan perbatasan yang dilaksanakan oleh DPD asal pemilihan Kalimantan Barat. Artikel 3 membicarakan kesejahteraan masyarakat perbatasan yang butuh perhatian pemerintah. Artikel 4 memberikan perhatian pada minuman keras asal malaysia. Artikel 5 membicarakan mengenai pentingnya pengamanan di perbatasan. Artikel 6 lebih pada infrastruktur diperbatasan yang butuh perhatian. Artikel 7 membincangkan mengenai pentingan penguatan daerah pinggiran dalam berbagai hal. Artikel 8 membicarakan menganai narkoba yang dipasok dari Malaysia. Kemudian artikel 9 membincangkan mengenai rawannnya 
wilayah perbatasan terhadap penyeludupan narkoba.

Jika kita tarik benang merahnya, artikel yang diturunkan Harian Pontianak Post dalam bulan Agustus hanya membicarakan dua tema besar, yaitu mengenai kesejahteraan masyarakat perbatasan. Hal ini dapat kita lihat pada artikel 2, 3, 5, 6 dan 7. Sedangkan pada artikel 1, 4, 8 dan 9 membincangkan mengenai perdagangan ilegal diperbatasan, khususnya mengenai penyeludupan gula, minuman keras dan narkoba asal Malaysia.

Kesembilan topik yang diangkat dalam artikel Harian Pontianak Post pada bulan Agustus 2015 tersebut, empat di antaranya menempati koran satu. Dua artikel menempati koran dua. Tiga artikel selebihnya menempati koran tiga. Jika kita lihat secara spesifik berdasarkan halaman artikel, hanya tiga artikel yang menempati halaman pertama pada koran satu. Selebihnya, enam artikel menempati koran dua dan tiga, dengan halaman yang berbeda pula. Tiga artikel yang menjadi headline tersebut adalah artikel 1 dengan judul "Polisi Grebeg Gudang Gula Ilegal". Kemudian artikel 8 dengan judul "Sita Narkoba Rp. 9.4 Milyar. Selanjutnya adalah artikel 9 dengan judul "Perbatasan Rawan Penyeludupan Narkoba".
Berbeda dengan Harian Pontianak Post, Harian Tribun Pontianak dalam agendanya pada bulan Agustus tahun 2015 hanya menurunkan lima artikel terkait dengan isu perbatasan. Artikel tersebut seperti yang dimuat Harian Tribun Pontianak pada tanggal 10, 13, 24 dan 31 Agustus 2015. Artikel tanggal 10 Agustus berjudul "Pemerintah Atur Wilayah Kerja Dokter". Artikel tanggal 13 Agustus berjudul "Gali Persoalan Perbatasan". Tanggal 24 Agustus Harian Tribun menurunkan dua artikel yaitu, "Jokowi Gesa Jalan Paralel" dan "Tekan Logistik". Sedangkan Artikel tanggal 31 Agustus berjudul "Buka Jalur Angkutan Perbatasan".

Keseluruhan artikel Harian Tribun Pontianak pada bulan Agustus 2015 jika kita tarik benang merahnya hanya membicarakan tiga hal. Pertama, membicarakan mengenai akses dan transportasi diperbatasan. Pembicaraan mengenai akses dan transportasi diperbatasan ini dapat kita lihat pada artikel tanggal 24, yang terdiri dari dua judul berita, yaitu "Jokowi Gesa Jalan Paralel" dan "Tekan Logistik". Topik mengenai akses jalan dalan transportasi ini juga dapat kita baca pada artikel tanggal 31 Agustus tahun 2015. Kedua, membicarakan mengenai wilayah kerja dokter. Tentang hal ini dapat kita lihat pada artikel tanggal 10 dengan judul 
"Pemerintah Atur Wikayah Kerja Dokter". Ketiga, Harian Tribun Pontianak mengangkat usaha pemerintah menyerap aspirasi masyarakat, terutama di perbatasan. Mengenai hal ini dapat kita lihat pada artikel tanggal 13 Agustus tahun 2015 yang berjudul "Gali Persoalan Perbatasan".

Berdasarkan

pengamatan

peneliti, artikel-artikel yang diturunkan Harian Tribun Pontianak pada bulan Agustus tahun 2015, hanya ada dua artikel yang menjadi headline atau menempati koran satu halaman pertama.

Artikel tersebut diturunkan pada tanggal 24 Agustus tahun 2015. Artikel yang pertama berjudul "Jokowi Gesa Jalan Paralel". Kemudian, artikel yang diturunkan pada hari yang sama, berjudul "tekan logistik". Artikel yang disebutkan terakhir merupakan pendalaman dari artikel yang disebutkan sebelumnya. Sedangkan artikel selebihnya, menempati koran dua dengan penempatan pada halaman belakang pula.

Selanjutnya dalam bulan September, berdasarkan pengamatan peneliti hanya ada empat artikel Harian Pontianak Post terkait isu perbatasan, yaitu artikel 10, 11, 12 dan 13. Artikel tanggal 10 September 2015 berjudul "masyarakat perbatasan harus paham hukum". Selanjutnya artikel tanggal 11
September 2015 berjudul "penuhi layanan siaran, RRI hadir hingga perbatasan". Artikel tanggal 12 September 2015 berjudul "BNNK gelar dialog khusus di RRI Entikong. Terakhir adalah artikel tanggal 18 September yang berjudul "Batas negara sasaran trans".

Berbeda dengan Harian Pontianak Post, Harian Tribun Pontianak tidak menurunkan artikel perbatasan pada bulan September tahun 2015. Berdasarkan pengamatan peneliti tidak ditemukan artikel atau berita mengenai perbatasan pada bulan September tahun 2015, sekalipun sekedar berita ringan. Tidak diketahui penyebabnya, padahal jika dibandingkan dengan Harian Pontianak Post yang menurunkan empat berita terkait isu perbatasan, semestinya Tribun Pontianak juga setidaknya ada jika tidak mau mengatakan sama atau melebihi artikel Pontianak Post. Bisa jadi peristiwa yang terjadi di bulan ini tidak menjual bagi Harian Tribun Pontianak.

Dalam bulan Oktober tahun 2015, Harian Pontianak Post menurunkan dua artikel terkait isu perbatasan. Artikel pertama diterbitkan tanggal 10 Oktober tahun 2015 membicarakan menganai adan Perbatasan Nasional Perbatasan yang membagikan peta untuk masyarakat perbatasan. Artikel ini berjudul "Badan perbatasan bagikan 
peta". Sedangkan artikel kedua seperti yang terlihat pada tanggal 12 Oktober tahun 2015. Artikel ini berjudul "menanti dry port Entikong".

Pada bulan yang sama, Harian Tribun Pontianak menurunkan tiga artikel terkait isu perbatasan. Tiga artikel tersebut diterbitkan pada tanggal 1, 4 dan 6 Oktober tahun 2015. Artikel tanggal 1 Oktober berjudul "Intel sita gula Malaysia". Artikel tanggal 4 Oktober berjudul "Bangun jalan patroli $30 \mathrm{Km}$ ". Kemudian artikel tanggal 6 Oktober berjudul "Polisi sita 1 ton gula Thailand". Jika kita tarik "benang merahnya", artikel Harian Tribun Pontianak bulan Oktober ini hanya membicarakan dua topik, yaitu mengenai jalan dan transportasi dan perdagangan ilegal.

Data dan fakta penelitian di atas menunjukkan bahwa harian Pontianak Post lebih intensif dibandingkan harian Tribun Pontianak dalam pemberitaannya mengenai isu perbatasan. Dalam tiga bulan yang menjadi objek penelitian ini, harian Pontianak Post menurunkan 15 artikel terkait perbatasan. Sementara pada bulan yang sama harian Tribun Pontianak hanya menurunkan delapan artikel mengenai perbatasan. Artinya, pemberitaan harian Pontianak Post mengenai isu perbatasan hampir dua kali lipat dibandingkan harian Tribun Pontianak, terlepas apakah artikel tersebut menempati posisi headline atau hanya sebagai pelengkap.

Intensifitas harian Pontianak Post ini dipresentasikan dari jumlah berita headline atau berita yang menempati koran 1 halaman 1, dimana harian Pontianak Post lebih banyak jumlahnya dibandingkan harian Tribun Pontianak. Terdapat 3 berita headline harian Pontianak Post, sementara harian Tribun hanya 2 berita headline.

Intensifitas ini juga dapat dilihat dari kedalaman berita yang disampaikan. Dari lima belas artikel atau berita harian Pontianak Post mengenai perbatasan, tiga di antaranya adalah berita panjang, sisanya adalah berita dengan panjang sedang dan berita pendek. Sementara pada harian Tribun Pontianak hanya ada satu berita atau artikel panjang dan mendalam, selebihnya adalah artikel pendek.

Perbedaan madia dalam melihat realitas sosial merupakan hal yang wajar. Hal itu dikarenakan masing-masing media mengusung ideologi yang mempengaruhi bagaimana peristiwa diberitakan. Karenanya, tidaklah mengherankan peristiwa yang sama diberitakan secara berbeda. Mekanisme pasar juga menjadi faktor yang sangta mempengaruhi konstruksi berita.

Sebagai agen konstruksi, media merupakan wadah yang strategis dalam 
rangka mengkonstruksi realitas sosial. Hal ini, merujuk kepada berbagai macam kepentingan di dalamnya, baik politik, ekonomi, sosial budaya dan agama. Dalam konteks politik dan kekuasaan, media, sebagaimana penjelasan sebelumnya, menjadi alat hegemoni untuk mempertahankan dominasi dan kekuasaan kelas yang mendominasi.

Dalam prakteknya, media melakukan seleksi terhadap wacana (berita) yang akan siarkan. Proses ini adalah keseluruhan aktivitas yang komplek dan rumit. Tidak sekedar itu, proses selektif juga dikakukan dalam penempatan terhadap berita tertentu, pilihan kata, struktur bahasa, dan gaya bercerita yang telah ditetapkan. Dalam kajian kritis, proses ini biasanya disebut framing, yaitu bagaimana media membingkai sebuah peristiwa sosial dalam realitas konstruksinya (berita).

Kajian kritis memandang bahwa proses produksi berita di madia massa merupakan pertarungan ideologis atau kepentingan tertentu. Pertarungan itu yang kemudian menghasilkan teks berita sebagai simbol-simbol yang mencerminkan dominasi ide dan kepentingan dari kelompok yang memenangkannya. News room sebagaimana arena sosial lainya terdiri dari seperangkat struktur dan agensi serta hubungan-hubungan di antaranya.
Struktur dalam news room dapat berupa peraturan yang tertulis maupun tidak tertulis, kebiasaan-kebiasaan, sumber daya dibutuhkan untuk beroperasinya news room tersebut, serta tatanan hubungan antara human agent yang berinteraksi di dalamnya. Human agent merujuk pada setiap orang yang memiliki wewenang dan tanggung jawab masingmasing dalam news room, yaitu wartawan, editor, redaktur, kameramen, presenter, penanggng jawab, bidang usaha, wakil penguasa atau negara dan lain-lain. Sedangkan agensi adalah tindakan-tindakan sosial dari para human agents tersebut. Dedy Hidayat (2000: 432), menjelaskan pilihan terhadap dualitas dan dualisme srukturagensi harus dilakukan sesuai dengan kondisi empirik dan spesifik. Masingmasing memiliki tugas dan wewenang tersendiri. Dalam suatu setting sosial tertentu, konsepsi dualisme mungkin lebih tepat, namun dalam setting yang lain konsep dualisme justru lebih memadai.

Terkait posisi struktur dan human agent, dapat dilihat dengan dua pendekatan. Pertama, menurut pandangan aliran instrumentalism, human agent selalu dapat menjadikan media (termasuk strukturnya) sebagai instrumen mereka. Chomsky dan Herman (1988: xi) adalah orang yang 
pernah menggambarkan dimana pemilik modal mampu menetapkan premispremis wacana publik, menentukan informasi apa yang boleh dikonsumsi publik dan terus-menerus mengelola pendapat publik melalui propaganda. Di sisi lain pendekatan ini juga mengakui kemanpuan jurnalis untuk memproduksi berita sebagaimana yang mereka inginkan, dan karena itu jurnalis juga dapat menjadikan media sebagai instrumen mereka.

Kedua, dengan pendekatan strukturalisme. Pendekatan strukturalism berpendapat bahwa isi media sematamata merupakan representasi dari struktur yang ada, mengabaikan interaksi sosial antara agen pelakunya. Bahkan menurut Schudson (Hidayat, 2000: 437) hasil dari produksi berita berkaitan langsung dengan struktur ekonomi media atau industri media. Sedangkan hal-hal lain di antaranya merupakan sebuah "black box" yang tidak bermanfaat untuk diperiksa. Dalam konteks ini, Golding dan Murdoch (J. Curran, dalam J. Curran \& M. Gurevitch, 1996: 19) memberikan alternatif lain dengan menyatakan bahwa sesungguhnya terdapat interplay antara struktur dan agensi. Dijelaskan Golding dan Murdoch bahwa, human agent beroperasi dalam struktur-struktus yang mungkin saja menghambat atau memfasilitasi, memaksa batas-batas tertentu atau menawarkan peluangpeluang.

Dengan demikian, keseluruhan dinamika yang terjadi pada ruang berita dapat dilihat sebagai serangkaian kecil interaksi antara sruktur dan agensi pada beberapa konteks historis spesifik, secara khusus sebagai kontestasi antara pemilik dan jurnalis dikaitkan dengan peluang dan kemampuan mereka menguasai elemen-elemen pada struktur, dimana kontestasi ini dilatarbelangi oleh ideologi masingmasing (sejalan dengan perkembangan kapitalisme tertentu).

Untuk mempertegas penjelasan konseptual mengenai dinamika yang terjadi dalam proses produksi berita di news room, serta kecenderungan atau perbedaan setiap media dalam memproduksi berita, dapat diketahui dari pelapisan-pelapisan yang ada dalam industri media dan turut mempengaruhi teks berita. Dalam konteks ini konsep Pamela J. Shoemaker dan Stephen D. Reese (Sobur, 2001: 138-139), membuat model "hierarchy of influence"' yang dapat menjelaskan hal ini, sebagai berikut: 
Gambar 4.1: "Hierarchy of Influence" Shoemaker \& Reese

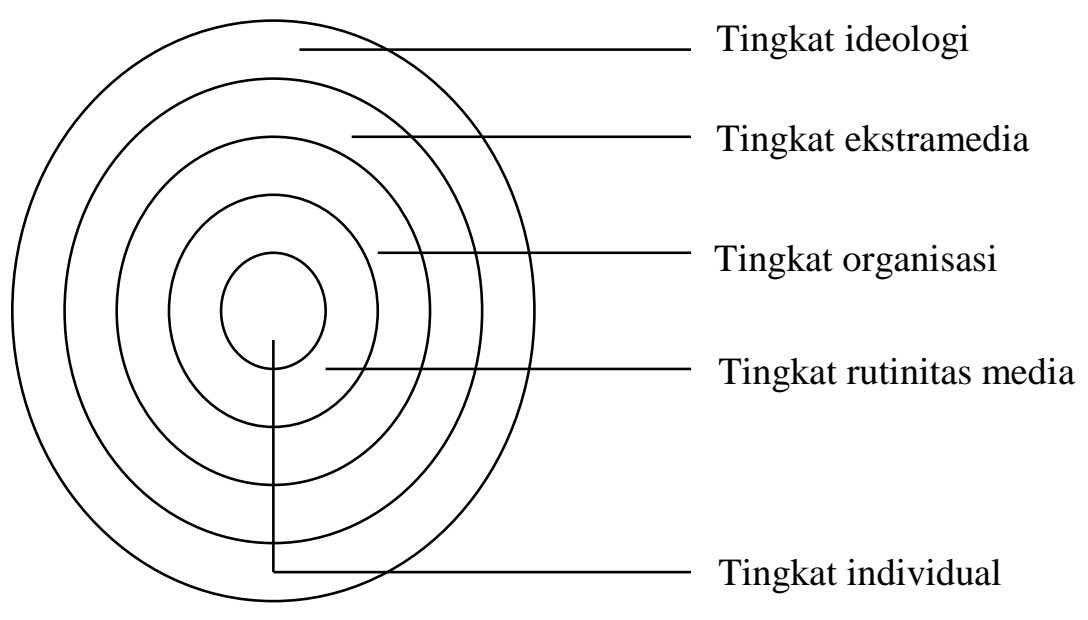

Sumber: Shoemaker \& Reese, 1993, dalam Alex Sobur, 2000: 138

Pertama, pengaruh individuindividu pekerja media. Di antara pengaruh-pengaruh ini adalah karakteristik pekerja komunikasi, latar belakang profesional dan kepribadian, sikap pribadi, dan peran-peran peofesional.

Kedua, pengaruh rutinitas media. Apa yang dihasilkan oleh media massa dipengaruhi oleh kegiatan seleksi-seleksi yang dilakukan oleh komunikator, termamsuk tenggat (deadline) dan rintangan waktu yang lain, keterbatasan tempat (space), struktur piramida terbalik dalam penulisan berita dan kepercayaan reporter pada sumber-sumber resmi dalam berita yang dihasilkan.

Ketiga, pengaruh organisasi. Salah satu tujuan yang ingin dicapai oleh media adalah mencari keuntungan materiil. Tujuan-tujuan dari media akan berpengaruh pada isi yang dihasilkan.

Empat, pengaruh dari luar organisasi (ekstramedia). Pengauh ini meliputi lobi dari kelompok kepentingan terhadap isi media, pseudoevent dari praktisi public relations dan pemerintah yang membuat peraturan-peraturan dibidang pers.

Lima, pengaruh ideologi. Ideologi merupakan sebuah pengaruh yang paling menyeluruh dari semua pengaruh. Ideologi di sini diartikan sebagai mekanisme simbolik yang menyediakan kekuatan kohesif yang mempersatukan di dalam masyarakat.

\section{Penempatan berita mengenai perbatasan pada suratkabar Harian Pontianak Post dan Tribun Pontianak.}


Penempatan berita mengenai perbatasan pada Harian Pontianak Post dan Tribun Pontianak selama bulan, Agustus, September dan Oktober tahun 2015 yang menjadi fokus penelitian begitu dinamis. Dinamis, karena kedua Harian ini tidak sama dalam "melihat" realitas di lapangan. Satu peristiwa yang sama "dibaca" secara berbeda. Penelitian ini mencoba melihat perbedaan antara Harian Pontianak Post dan Tribun Pontianak dalam menempatkan pemberitaan mengenai perbatasan selama bulan Agustus, September dan Oktober tahun 2015.

Bulan Agustus tahun 2015, Harian Pontianak Post menurunkan sembilan artikel mengenai perbatasan. Artikel-artikel ini ditulis dan ditempatkan sesuai tingkat kepentingannya. Dari pengamatan peneliti hanya ada tiga artikel yang menjadi headline, menempati halaman satu koran satu. Tiga artikel tersebut adalah "Polisi grebek gudang ilegal" yang diturunkan pada tanggal 6 Agustus tahun 2015. Selanjutnya artikel tanggal 25 Agustus tahun 2015, yang berjudul "Sita narkoba Rp. 9.4 Milyar. Terakhir adalah artikel tanggal 28 Agustus tahun 2015 yang berjudul "Perbatasan rawan penyeludupan narkoba".

Satu artikel diturunkan pada koran 1 namun ditempatkan pada halaman 8, dengan judul "Perbatasan butuh perhatian".

Kemudian dua artikel menempati koran dua. Yaitu artikel tanggal 12 dan 24 Agustus tahun 2015. Artikel tanggal 12 berjudul "Tingkatkan pengamanan perbatasan". Artikel ini diturunkan pada koran 2 dan ditempatkan pada halaman 12. Selanjutnya arikel yang menempati koran 2 adalah, artikel yg diturunkan tangal 22 Agustus 2015, yang berjudul "Perkuat daerah pinggiran". Artikel ini ditempatkan pada halaman 18.

Artikel lainnya diturunkan pada koran 3 dengan halaman yang berbada pula. Berdasarkan pengamatan peneliti terdapat 3 artikel yang menempati koran 3, yaitu artikel tanggal 6 Agustus tahun 2015, dengan judul "DPD gelar eksaminasi legal pengelolaan perbatasan. Selanjutnya pada tanggal 8 Agustus tahun 2015 dengan judul artikel "Perhatikan kesejahteraan masyarakat perbatasan". Terakhir adalah artikel tanggal 10 Agustus 2015 dengan judul "Ratusan minol asal Jiran disita".

Pada bulan yang sama, Harian Tribun Pontianak menurunkan lima artikel terkait isu perbatasan. Artikelartikel tersebut diturunkan pada tanggal 10, 13, 24 dan tanggal 31 Agustus tahun 2015. Dua artikel menempati koran 1 halaman 1, dan 3 artikel menempati 
koran 2 dengan halaman yang berbeda pula.

Artikel yang menempati koran 1 halaman 1 atau headline, yaitu artikel pada tanggal 24 Agustus 2015. Pada hari ini harian Tribun Pontianak menurunkan dua bertia sekaligus, dan keduanya menempati koran 1 halaman 1. Artinya, dibandingkan artikel lainnya yang ada pada bulan Agustus, kedua artikel ini sangat penting untuk diketahui publik. Artikel pertama berjudul "Jokowi gesa jalan paralel". Sedangkan artikel kedua berjudul "tekan logistik". Artikel kedua ini merupakan pendalaman daari artikel pertama yang mencoba melihat arti penting jalan paralel dilihat dari perspektif para pengusaha.

Sedangkan 3 artikel lainnya menempati koran dan halaman selain koran dan halaman 1. Artikel-artikel ini seperti yang terlihat pada tanggal 10, 13 dan 31 Agustus 2015. Artikel tanggal 10 berjudul "Pemerintah atur wilayah kerja dokter". Artikel tanggal 13 berjudul "Gali persoalan perbatasan". Terakhir, artikel tanggal 31 berjudul "Buka jalur angkutan perbatasan".

Dalam bulan September 2015, harian Pontianak Post menurunkan empat artikel mengenai perbatasan. Artikel-artikel tersebut seperti yangyang dipublis pada tanggal 10, 11, 15 dan 18 September 2015. Empat artikel ini menempati koran dan halaman yang berbeda. Berdasarkan pengamatan peneliti, tiga artikel menempati koran 2 yaitu artikel tanggal 10 menempati 19, artikel tanggal 11 menempati halaman 1 dan artikel tanggal 18 menempati halaman 1. Kemudian satu artikel menempati koran 3 dan halaman 28 . Artinya, pada bulan ini tidak ada satupun isu perbatasan menjadi headline atau berita utama pada harian Pontianak Post.

Jika dilihat pesan yang dibicarakan, artikel tanggal 10 September 2015 Semembicarakan menganai keharusan masyarakat perbatasan untuk memahami hukum. Artikel ini berjudul "Masyarakat perbatasan harus paham hukum". Artikel tanggal 11 September 2015 berbicara mengenai peran $\mathrm{RRI}$ dalam memenuhi kebutuhan informasi masyarakat perbatasan. Artikel ini berjudul "Penuhi layanan siaran, RRI hadir hingga perbatasan". Kemudian artikel tanggal 15 September 2015 membicarakan mengenai dialog BNNK di RRI Entikong. Terakhir adalah artikel tanggal 18 September 2015 yang membicarakan mengenai batas negara sebagai sasaran trans.

Sementara pada pada bulan yang sama tidak ditemukan pembicaraan mengenai perbatasan pada harian Tribun 
Pontianak. Padahal jika kita melihat pada harian Pontianak Post terdapat empat isu perbatasan yang diekspose kepada masyarakat. Artinya, ada pembicaraan atau conten yang dibicarakan mengenai perbatasan, meskipun bukan headline atau isu penting. Artinya pada bulan ini, harian Tribun Pontianak "diam" terhadap isu perbatasan. Ada dua kemungkinan besar, pertama isu perbatasan yang mengemuka pada bulan ini dianggap tidak begitu penting untuk diketahui oleh masyarakat bagi harian Tribun Pontianak. Hal ini terkait mekanisme pada dapur redaksi. Kajian ini tidak melihat hiruk pikuk pada riang redaksi. Kedua, bisa jadi isu-isu yang diangkat pada harian Pontianak Post pada bulan ini hanya sekedar pelengkap - hanya untuk memenuhi halaman. Ada dua indikasi ke arah itu, pertama memang apa yang dibicarakan harian Pontianak Post pada bulan ini tidak terdapat di harian Tribun Pontianak. Kedua, apa yang dibicarakan Pontianak Post tersebut terdapat pada koran belakang yanitu koran 2 dan 3.

Pada bulan Oktober harian Pontianak Post menurunkan dua artikel mengenai perbatasan. Kedua artikel tersebut masing-masing pada tanggal 10 dan 12 Oktober tahun 2015. Artikel tanggal 10 membicarakan mengenai aktivitas pembagian peta untuk masyarakat perbatasan oleh Badan Perbatasan. Artikel ini berjusul "Badan Perbatasan bagikan peta". Artikel tanggal 12 membicarakan mengenai pentingnya keberadaan Dry Port Entikong. Artikel ini berjudul "Menanti Dry Port Entikong".

Secara penempatan, artikelartikel Pontianak Post pada bulan ini koran 3 dengan halaman yang berbeda. Misalnya, artikel tanggal 10 yang menempati halaman 28 koran 1. Sedangkan artikel 12 menempati halaman 1 koran 3. Artinya, pada bulan ini tidak terdapat isu penting maupun sangat penting pada harian Pontianak Post terkait perbatasan. Karena artikelartikel tersebut menempati koran dan dan halaman belakang.

Sementara pada bulan yang sama harian Tribun Pontianak menurukan tiga artikel mengenai perbatasan. Masing-masing pada tanggal 1, 4 dan 6 Oktober 2015. Berdasarkan pengamatan peneliti, isu perbatasan pada harian Tribun Pontianak pada bulan ini menempati koran dan halaman yang beragam. Satu artikel menempati koran 1 dan halaman 3, yaitu artikel tanggal 4 Oktober 2015. Artikel ini berjudul "Bangun jalan patroli $30 \mathrm{Km}$ ". Sedangkan dua artikel lainnya menempati koran 2. Artikel tanggal 1 Oktoner 2015 berjudul "Intel sita gula Malaysia" menempati koran 2 halaman 
11. Terakhir adalah artikel tanggal 6 Oktober 2015 berjudul "Polisi sita 1 ton gula Thailand". Artikel ini menempati koran 2 halaman 1.

Berdasarkan fakta di atas terdapat perbadaan kedua media ini dalam menentukan isu dan penempatannya sebagai headline. Sebagai contoh, harian Pontianak Post tanggal 6 Agustus 2015 menempatkan kasus penggerebekan gudang gula ilegal sebagai headline, namun kasus ini tidak menjadi perhatian harian Tribune Pontianak dan bahkan tidak diberitakan sama sekali.

Hal yang sama juga diperlihatkan pada pemberitaan harian Pontianak Post tanggal 25 Agustus 2015. Harian Pontianak Post hari ini menjadikan kasus penyitaan narkonba 9,4 Milyar sebagai topik utama. Namun hal ini tidak terjadi pada harian Tribune Pontianak. Berdasarkan penelusuran peneliti, kasus ini bahkan tidak diangkat oleh harian Tribun Pontianak, sekalipun hanya sekedar pelengkap - kalau tidak sebagai topik utama. Padahal jika kita melihat substansinya, kasus ini termasuk topik penting yang harus diketahui publik.

Harian Pontianak Post tanggal 28 Agustus memberitakan mengenai daerah perbatasan yang rawan terhadap penyeludupan narkoba sebagai headline. Artikel ini bahkan tergolong panjang.
Namun, sama seperti dua headline yang telah dipaparkan di atas, fenomena ini tidak menjadi perharian harian Tribun Pontianak. Pengamatan peneliti menunjukkan bahwa topik yang diangkat dan menjadi heladline harian Pontianak Post pada tanggal yang sama bahkan tidak diangkat sama sekali pada harian Tribun Pontianak sama sekali.

Sebaliknya, topik yang menjadi dua topik utama pada harian Tribun Pontianak tanggal 24 Agustus 2015 tidak menjadi perhatian harian Pontianak Post. Berdasarkan amatan peneliti, yang menjadi fakus harian Tribun Pontianak ini bahkan tidak diberitakan sama sekali oleh Pontianak Post.

Perbedaan dalam pembacaan isu perbatasan dan penempatannya dalam pemberitaan merupakan adalah sebuah kewajaran dalam kajian kritis. Hal ini sangat terkait dengan kekanisme pada news room. Dalam prakteknya, media melakukan seleksi terhadap wacana (berita) yang akan siarkan. Proses ini adalah keseluruhan aktivitas yang komplek dan rumit. Tidak sekedar itu, proses selektif juga dikakukan dalam penempatan terhadap berita tertentu, pilihan kata, struktur bahasa, dan gaya bercerita yang telah ditetapkan. Dalam kajian kritis, proses ini biasanya disebut framing, yaitu bagaimana media membingkai sebuah peristiwa sosial 
dalam realitas konstruksinya (berita). Framing media terhadap realitas sosial tersebut dipengaruhi oleh irisan-irisan yang yang mewarnai praktek kerja media sebagai mana yang dikatakan Bekker, di antaranya adalah mekanisme pasar.

\section{Kesimpulan}

Berdasarkan pembahasan pada bab sebelumnya, penelitian ini menyimpulkan bahwa isu perbatasan diberitakan secara berbeda dalam pewacanaan harian Pontianak Post dan harian Tribun Pontianak. Perbedaan ini dapat dilihat dari dua indikator sebagai berikut:

Pertama, secara intensitas, harian Pontianak Post lebih intensif dibandingkan harian Tribun Pontianak dalam pemberitaannya mengenai isu perbatasan. Intensitas ini dapat dilihat misalnya dari jumlah pemberitaan mengenai perbatasan pada harian Pontianak Post jauh lebih tinggi dibandingkan harian Tribun Pontianak. Dalam tiga bulan yang menjadi objek penelitian ini, harian Pontianak Post menurunkan 15 artikel terkait perbatasan. Sementara pada bulan yang sama harian Tribun Pontianak hanya menurunkan delapan artikel mengenai perbatasan. Artinya, pemberitaan harian Pontianak Post mengenai isu perbatasan hampir dua kali lipat dibandingkan harian
Tribun Pontianak, terlepas apakah artikel tersebut menempati posisi headline atau hanya sebagai pelengkap. Intensifitas harian Pontianak Post ini dipresentasikan dari jumlah berita headline atau berita yang menempati koran 1 halaman 1, dimana harian Pontianak Post lebih banyak jumlahnya dibandingkan harian Tribun Pontianak. Terdapat 3 berita headline harian Pontianak Post, sementara harian Tribun hanya 2 berita headline. Intensifitas ini juga dapat dilihat dari kedalaman berita yang disampaikan. Dari lima belas artikel atau berita harian Pontianak Post mengenai perbatasan, tiga di antaranya adalah berita panjang, sisanya adalah berita dengan panjang sedang dan berita pendek. Sementara pada harian Tribun Pontianak hanya ada satu berita atau artikel panjang dan mendalam, selebihnya adalah artikel pendek.

Kedua, terdapat perbedaan antara harian Pontianak Post dan Tribun Pontianak dalam menentukan berita headline terkait isu perbatasan. Berdasarkan fakta di atas terdapat perbadaan kedua media ini dalam menentukan isu dan penempatannya sebagai headline. Sebagai contoh, harian Pontianak Post tanggal 6 Agustus 2015 menempatkan kasus penggerebekan gudang gula ilegal sebagai headline, namun kasus ini tidak 
menjadi perhatian harian Tribune Pontianak dan bahkan tidak diberitakan sama sekali.

Hal yang sama juga diperlihatkan pada pemberitaan harian Pontianak Post tanggal 25 Agustus 2015. Harian Pontianak Post hari ini menjadikan kasus penyitaan narkonba 9,4 Milyar sebagai topik utama. Namun hal ini tidak terjadi pada harian Tribune Pontianak. Berdasarkan penelusuran peneliti, kasus ini bahkan tidak diangkat oleh harian Tribun Pontianak, sekalipun hanya sekedar pelengkap - kalau tidak sebagai topik utama. Padahal jika kita melihat substansinya, kasus ini termasuk topik penting yang harus diketahui publik.

Harian Pontianak Post tanggal 28 Agustus 2015 memberitakan mengenai daerah perbatasan yang rawan terhadap penyeludupan narkoba sebagai headline. Artikel ini bahkan tergolong panjang. Namun, sama seperti dua headline yang telah dipaparkan di atas, fenomena ini tidak menjadi perharian harian Tribun Pontianak. Pengamatan peneliti menunjukkan bahwa topik yang diangkat dan menjadi heladline harian Pontianak Post pada tanggal yang sama bahkan tidak diangkat sama sekali pada harian Tribun Pontianak sama sekali.

Sebaliknya, topik yang menjadi dua topik utama pada harian Tribun Pontianak tanggal 24 Agustus 2015 tidak menjadi perhatian harian Pontianak Post. Berdasarkan amatan peneliti, yang menjadi fakus harian Tribun Pontianak ini bahkan tidak diberitakan sama sekali oleh Pontianak Post.

\section{E. Daftar Pustaka}

\section{Buku :}

Alex Sobur, 2001. Analisis Teks Media, Bandung: PT. Remaja Rosdakarya; Arthur Asa Berger, 1991. Media Analysis Techniques, resived edition, Beverly Hills : Sage Publication;

Burhan Bungin, 2008. Konstruksi Sosial Media Massa, Jakarta: Kencana;

Bachtiar Effendy, 2000. "Media Massa dan Politik" dalam Sudrajat A.S (ed), Repolitisasi Islam: Pernahkah Islam Berhenti Berpolitik?, Bandung: Mizan;

Chris Barker, 2000. Cultural Studies: Theory dan Praktik, Nurhadi (penerjemah), Yogyakarta: Kreasi Wacana;

Dedy N. Hidayat, 2000. Revolusi Mei:

Runtuhnya Sebuah Hegemoni, Jakarta: Gramedia;

Deddy Mulyana, 2000. IImu Komunikasi, Suatu Pengantar. Bandung: PT. Remaja Rosdakarya;

McQuail, Dennis. McQuail's Mass Communication Theory. London : Sage Publications. 2000. 
Teori Komunikasi

Massa Suatu Pengantar.

Terjemahan Oleh Agus Dharma

Aminuddin. Jakarta : Erlangga, 1987.

E. Herman \& Noam Chomsky, 1988.

Manufacturing Consent, The

Political of Media, New York:

Pantheon;

Em Griffin, 2003. Communication

Theory, A First Look At (Fifth

Edition), New York: The McGRAW

- HILL COMPANIES, INC;

Eriyanto, 2001. Analisis Wacana, Jogjakarta: PT. LkiS Pelangi Aksara;

Idi Subandy Ibrahim \& Dedy Djamaludin Malik, 1997. Hegemoni Budaya, Yogyakarta: Bentang;

Hubbard, Jeffrey C., Melvin L. DeFleur and Lois B. DeFleur. Mass Media Influences on Public Conceptions of Social Problems. Social Problems Vol. 23, No. 1, California : University Of California Press. 1975.

John Fiske, 1990. Introduction to Communication Studies, second edition, London and New York: Routledge;

James Curran \& M. Guravitch, 1996. Media and Society, London: Edward Arnold;
Lexy J. Moleong, 1989. Metodologi Penelitian Kualitatif, Bandung: PT. Remaja Rosdakarya;

Norman K. Denzin \& Yvonna S. Lincoln, 2009. Handbook of Qualitative Research, Edisi Bahasa Indonesia, Yogyakarta: Pustaka Pelajar;

Nezar Patria \& Andi Arief, 2003. Antonio Gramsi; Negara \& Hegemoni, Jakarta: Pustaka Pelajar;

Pawito, 2007. Penelitian Komunikasi Kualitatif, Yogyakarta: LKis;

Roger Simon, 1999. Gagasan-Gagasan Politik Gramsci, Yogyakarta: Pustaka Pelajar \& Insist;

Stephen W. Littlejohn, 1996. Theories of Human Communication, Fifth Edition, New York: Warsworth Publishing Company;

Syaiful Arif, 2001. Pemikiran-Pemikiran Revolusioner, Malang: Averroes

Press \& Pustaka Pelajar;

Yasraf Amir Piliang, 2004. Posrealitas:

Realitas Kebudayaan Dalam Era

Posmetafisika, Yogyakarta:

Jalasutra;

Louis Althusser, 1984. Essay on Ideology, London: Verso;

\section{Suratkabar :}

Harian Pontianak Post, 6 Agustus 2015 Harian Pontianak Post, 8 Agustus 2015 Harian Pontianak Post, 10 Agustus 2015 Harian Pontianak Post, 12 Agustus 2015 Harian Pontianak Post, 22 Agustus 2015 Harian Pontianak Post, 25 Agustus 2015 
Harian Pontianak Post, 28 Agustus 2015 Harian Pontianak Post, 10 September 2015 Harian Pontianak Post, 15 September 2015 Harian Pontianak Post, 18 September 2015

Harian Pontianak Post, 10 Oktober 2015

Harian Pontianak Post, 12 Oktober 2015

Harian Tribun Pontianak, 10 Agustus 2015

Harian Tribun Pontianak, 13 Agustus 2015

Harian Tribun Pontianak, 24 Agustus 2015

Harian Tribun Pontianak, 31 Agustus 2015

Harian Tribun Pontianak, 1 Oktober 2015 Harian Tribun Pontianak, 4 Oktober 2015 Harian Tribun Pontianak, 6 Oktober 2015
Harian Tribun Pontianak, 10 Agustus 2015

\section{Internet :}

Eusabinus Bunau dkk, (tanpa tahun). Aksesibilitas dan partisipasi, http://download.portalgaruda.org/article. diakses tanggal 24 Agustus 2015, pukul 15.06 WIB

Partnership for governance reform, 2011. Kebijakan pengelolaan kawasan perbatasan indonesia, .. .http://www.kemitraan.or.id/sites (diakses 24 agustus 2015, pukul 15.30) Sri rahayu $\mathrm{SH}, 2007$. Efektivitas Gugus... http://jurnal.untan.ac.id/index.php/nestor/ article/viewFile (diakses 11-11-2015) Sutaat, 2012. Pemberdayaan masyarakat daerah perbatasan.....http://puslit.kemsos.go.id/u pload/post/files/ (diakses, 12-11-2015) 